\title{
ASSESSMENT OF DIFFERENT MANAGEMENT SYSTEMS IN AN AREA OF CERRADO SENSU STRICTO
}

\author{
Flávia Nascimento de Souza ${ }^{1}$, José Roberto Soares Scolforo², Rubens Manoel dos Santos³,
} Charles Plínio de Castro Silva ${ }^{4}$

(received: March 23, 2010; accepted: November 30, 2010)

\begin{abstract}
This study aims to evaluate the effect of different management systems on the floristic composition and diversity of a fragment of Cerrado sensu stricto vegetation located in Brasilândia de Minas (MG), eleven years after interventions. In 1997, 30 plots were installed in the study site, in a random block design, consisting of ten treatments with three replications: 50\%, $60 \%, 70 \%$ and $80 \%$ removal of the basal area, involving $20 \%$ reduction and increase in the De Liocourt quotient value; clear cutting and control treatment. Prior to treatment installation, an inventory was compiled of original vegetation. In 2004 and 2008 further inventories were produced. It was observed that interventions in the relevant Cerrado area led to changes in the floristic composition and diversity of local vegetation, yet these changes were also observed in undisturbed areas which had not been subjected to management plans.
\end{abstract}

Key words: Floristic composition, diversity, resilience.

\section{AVALIAÇÃO DE DIFERENTES SISTEMAS DE MANEJO EM UMA ÁREA DE CERRADO SENSU STRICTO}

RESUMO: Objetivou-se, neste estudo, avaliar o efeito de diferentes sistemas de manejo na composição florística e na diversidade de uma vegetação de cerrado sensu stricto, localizado em Brasilândia de Minas (MG), onze anos após as intervenções. Em 1997, implantaram-se na área de estudo 30 parcelas, com delineamento em blocos casualizados, nas quais foram instalados dez tratamentos com três repetições: remoção de 50\%, 60\%, 70\% e 80\% da área basal, envolvendo redução e acréscimo de $20 \%$ no quociente de De Liocurt; corte raso e testemunha. Antes da implantação dos tratamentos, foi realizado um levantamento a fim de conhecer a vegetação original. Nos anos de 2004 e 2008, novos levantamentos foram realizados. Verificou-se que as intervenções em área de cerrado provocaram alterações na composição florística e na diversidade da vegetação, no entanto, essas alterações também foram verificadas em áreas onde não foram efetuados planos de manejo.

Palavras-chave: Composição florística, diversidade, resiliência.

\section{INTRODUCTION}

Cerrado is considered Brazil's second largest biome, well known for the mosaic of floristic forms present in it and also for its enormous biodiversity, which is estimated to include a third of the Brazilian biota and $5 \%$ of the world's flora and fauna (ALHO; MARTINS, 1995; RATTER; DARGIE, 1992). In Minas Gerais, the Cerrado is predominantly found in central, northwest and west portions of the state, occupying around $20 \%$ of its territory (CARVALHO; SCOLFORO, 2008).

Large areas of vegetation native to this biome are nevertheless being replaced or transformed in preparation for agricultural and forest crops or animal raising activities (DRUMMOND et al., 2005). And, since disorderly occupation and exploration of the Cerrado has been creating social, economic and environmental impact on these regions (OLIVEIRA et al., 1998), applying management techniques can be an effective strategy for securing sustainable use of this native vegetation.

Vegetation management is grounded in continuous and sustained production by a forest ecosystem in such way as to reach equilibrium between the output and ecological functions of that ecosystem (WAKEEL et al., 2005). Knowing and quantifying impacts on local vegetation after adopting management plans constitutes an important tool for assessing the performance of such plans (GOMES et al., 2004).

\footnotetext{
${ }^{1}$ Forest Engineer, M.Sc. Candidate in Forest Sciences - Departamento de Ciências Florestais - Universidade Federal de Lavras - Cx. P. 3037 37200-000 - Lavras, MG, Brasil - fleivians@yahoo.com.br

${ }^{2}$ Forest Engineer, Professor, Dr. in Forest Engineering - Departamento de Ciências Florestais - Universidade Federal de Lavras - Cx. P. 3037 37200-000 - Lavras, MG, Brasil - jscolforo@dcf.ufla.br

${ }^{3}$ Biologist, Professor Dr. in Ecology - Departamento de Ciências Florestais - Universidade Federal de Lavras - Cx. P. 3037 - $37200-000$ - Lavras, MG, Brasil - santosfloracaatinga@yahoo.com.br

${ }^{4}$ Agronomic Engineer, Ph.D. Candidate in Forest Sciences - Departamento de Ciências Florestais - Universidade Federal de Lavras - Cx. P. 3037 37200-000 - Lavras, MG, Brasil - charlesplinio@hotmail.com
} 
According to Martins (1999) and Oliveira and Rotta (1982), floristic analyses provide information on the species composition of a given plant community and on how species respond to disturbances, allowing better understanding of a forest's resilience capacity. The floristic composition can also be expressed by its diversity (REIS et al., 2007).

Given the above context, the objective of this work is to evaluate the behavior of the floristic composition and diversity of a fragment of Cerrado sensu stricto, located in Brasilândia de Minas (MG) and subjected to different sustainable management systems, eleven years after the relevant interventions.

\section{MATERIAL AND METHODS}

The study was conducted in an area of Cerrado sensu stricto around 343 ha in size, owned by V\&M Florestal, a company located in the municipality of Brasilândia de Minas (MG), at coordinates $17^{\circ} 02^{\prime} \mathrm{S}$ and $45^{\circ} 50^{\prime} \mathrm{W}$ and altitude $575 \mathrm{~m}$. According to Köppen classification, the local climate is Aw type, having a tropical system with dry winters. The average annual temperature is $22.5^{\circ} \mathrm{C}$ and the average annual precipitation is $1,441.5 \mathrm{~mm}$. Local soils include predominantly Cambisol, Red-Yellow Latosol and Dark-Red Latosol (OLIVEIRA et al., 2006).

In 1997, 30 ha $(600 \times 500 \mathrm{~m})$ containing three random blocks (200 x $500 \mathrm{~m}$ ) were demarcated in the above area. Each block was subdivided into ten plots, each $100 \times 100 \mathrm{~m}$ in size, and in the center of each plot a subplot was installed of $1,800 \mathrm{~m}^{2}$ (30 x $\left.60 \mathrm{~m}\right)$, where taxonomic identifications, $\mathrm{CBH}$ (circumference $1.30 \mathrm{~m}$ above ground) and total height measurements were taken of all individuals with CBH $15.7 \mathrm{~cm}$ or more. With these data it was possible to designate different management systems (treatments) to be implemented and also to know the floristic composition of original vegetation. Ten treatments were installed per block, distributed randomly across the plots (100 x 100 $\mathrm{m})$ : control (T); clear cut (CR); selective cut, with 50\% $(50 \mathrm{~N}), 60 \%(60 \mathrm{~N}), 70 \%(70 \mathrm{~N})$ and $80 \%(80 \mathrm{~N})$ removal of the basal area, maintaining a $20 \%$ reduction in the original De Liocourt quotient value for these four situations; and selective cut, with 50\% (50Q), 60\% (60Q), 70\% (70Q) and $80 \%$ (80Q) removal of the basal area, maintaining a $20 \%$ increase in the original De Liocourt quotient value for these four situations. This $20 \%$ increase and decrease in the original De Liocourt quotient value promotes, respectively, greater removal of individuals in large diameter classes and greater removal of individuals in small diameter classes.
In years 2004 and 2008, new inventories were compiled in the subplots $\left(1,800 \mathrm{~m}^{2}\right)$ in order to monitor the areas subjected to different management systems. In these inventories, all individuals with $\mathrm{CBH} 15.7$ $\mathrm{cm}$ or more were measured and identified. Botanical identification was done at the site using both specialized literature and consulting the herbarium of the Federal University of Lavras (ESAL Herbarium) and specialists. The Angiosperm Phylogeny Group (2003) classification system was adopted.

For analysis of the floristic composition before and after interventions, a record was kept of the presence and absence of species per treatment, for each inventory, and data were then compared for similarity, in pairs, using the Sorensen index (KENT; COKER, 1992). A dendrogram was constructed with this index using the unweighted arithmetic mean clustering method (UPGMA) (SNEATH; SOKAL, 1973), with the help of the STATISTICA software package, version 7.0 (STATSOFT, 2004), so as to view possible clusters.

With the Shannon diversity index (H') (BROWER; ZAR, 1984), floristic diversity was analyzed in the study site, per treatment, and results between the different inventories were compared in pairs using the Hutcheson t-test (MAGURRAN, 1988). To represent the uniformity of the distribution of individuals across the species sampled, the Pielou evenness index was calculated (J) (BROWER; ZAR, 1984) and the paired t-test was used to examine possible changes before and after the implementation of management regimes, after checking the normality of data difference by the Shapiro-Wilk test (FERREIRA, 2005). The Shapiro-Wilk test and the paired t-test were run using the R software package, version 2.9 (R DEVELOPMENT CORE TEAM, 2009).

\section{RESULTS AND DISCUSSION}

Based on the total area sampled, 5.4 ha (30 subplots, each $1,800 \mathrm{~m}^{2}$ in size), in year 1997 , which refers to the inventory prior to the implementation of management regimes, 60 species, 51 genera and 31 families were found, to a total of 4,577 individuals. As to the inventories following the application of treatments, in 2004 3,843 individuals were found, distributed among 65 species, 54 genera and 32 families, while in 2008 5,196 individuals were found, distributed among 74 species, 59 genera and 33 families. The list of species found in each of the three measurement occasions is illustrated in Table 1.

Cerne, Lavras, v. 17, n. 1, p. 85-93, jan./mar. 2011 
Table 1 - Species sampled in 30 subplots $\left(1,800 \mathrm{~m}^{2}\right)$ in the municipality of Brasilândia de Minas (MG), listed in alphabetical order of family, in three measurement occasions. Index 1 refers to species found in the first inventory (1997), while index 2 and index 3 refer to species found in the second (2004) and third inventories (2008) respectively.

Tabela 1 - Relação das espécies amostradas em 30 subparcelas $\left(1800 m^{2}\right)$ no município de Brasilândia de Minas (MG), em ordem alfabética de família, nas três ocasiões de medição. Em que, o índice 1 corresponde às espécies encontradas no primeiro levantamento (1997) e os índices 2 e 3 àquelas encontradas no segundo (2004) e terceiro levantamento (2008), respectivamente.

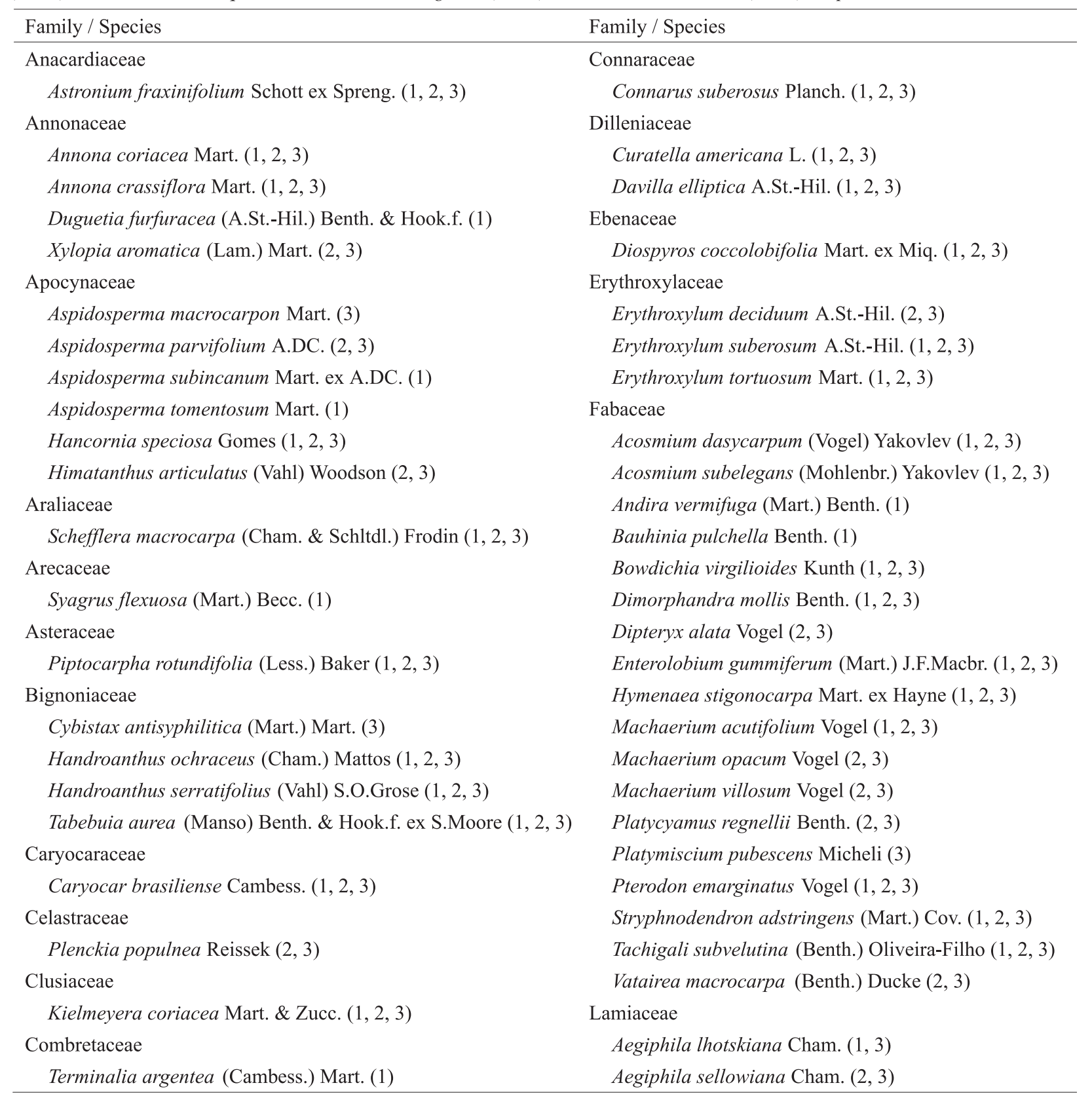




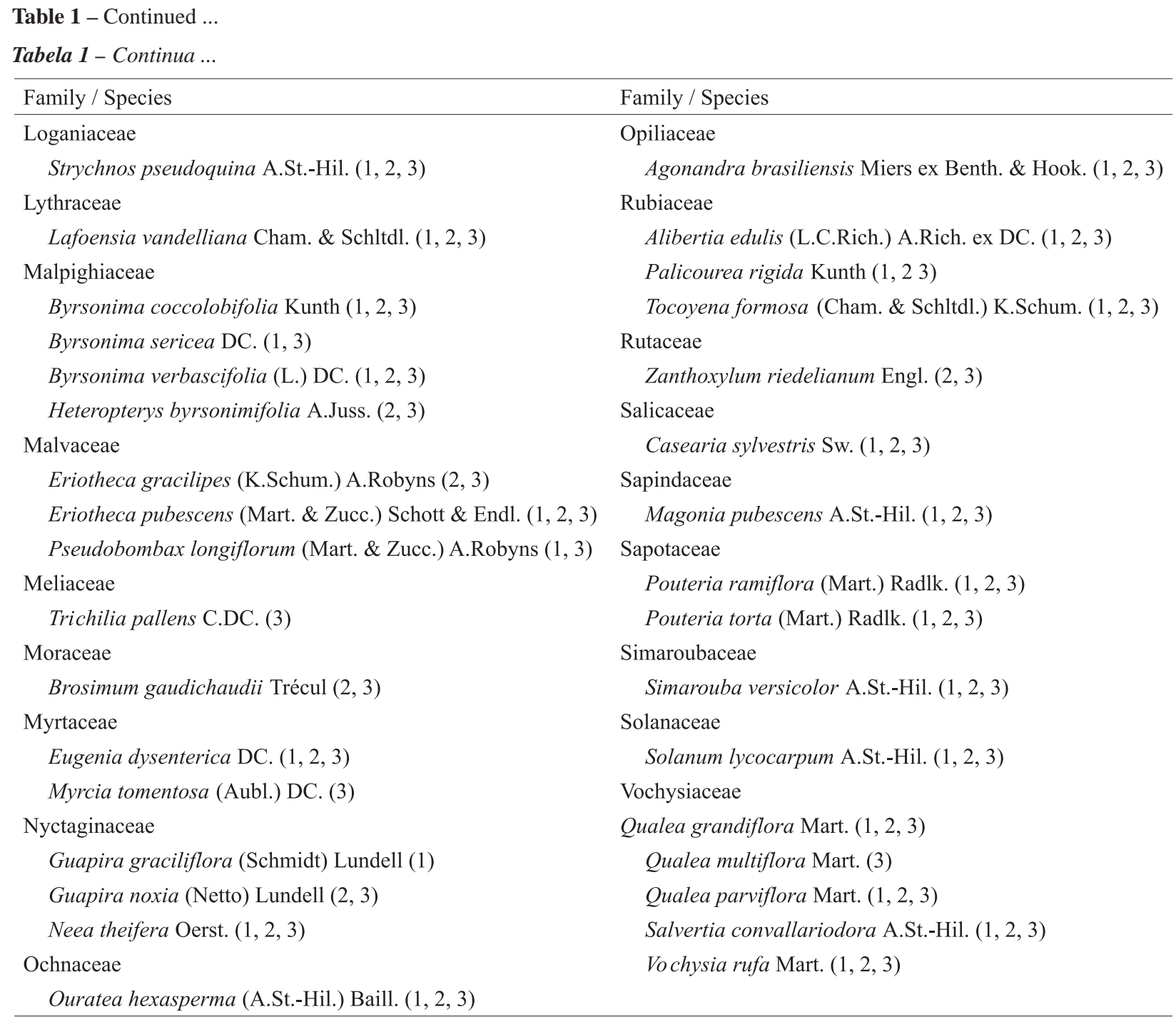

Family Fabaceae was found to have the largest number of species listed, before and after interventions (14 species on average). On the other hand, 19 families were represented by a single species. Fabaceae has been referred to in many Cerrado inventories as the family having the greatest species abundance (FIEDLER et al., 2004; SILVA et al., 2008; TEIXEIRA et al., 2004). Martins (1993) argues that the prevalence of this family could be related to the presence of root nodules which act as a nutrient retention and transfer mechanism (nitrogen) through the ecosystem, thus favoring the development of these species in Cerrado soils. Another possible reason for this family remaining top listed in the inventories following application of treatments is the fact that many species are heliophilous and emergent (LORENZI, 1992).

In analyzing the floristic composition per treatment (Table 2), it was observed that in 2008 the number of species, genera and families was equal to or higher than that found in 1997, regardless of treatment. This occurred as a function of the growth of individuals in the period in between assessments, contributing toward increased floristic richness, particularly in the treatment with no intervention, and also as a function of the management regimes, which favored the appearance of new species, genera and families in the intervention areas.

Cerne, Lavras, v. 17, n. 1, p. 85-93, jan./mar. 2011 
Table 2 - Number of species, genera and families of woody vegetation, before (1997) and after treatment implementation (2004 and 2008).

Tabela 2 - Número de espécies, gêneros e famílias da vegetação lenhosa, antes (1997) e após a implantação dos tratamentos (2004 e 2008).

\begin{tabular}{|c|c|c|c|c|c|c|c|c|c|}
\hline \multirow{2}{*}{ Treatment } & \multicolumn{3}{|c|}{ Species } & \multicolumn{3}{|c|}{ Genera } & \multicolumn{3}{|c|}{ Families } \\
\hline & 1997 & 2004 & 2008 & 1997 & 2004 & 2008 & 1997 & 2004 & 2008 \\
\hline $50 \mathrm{~N}$ & 32 & 40 & 46 & 27 & 34 & 40 & 20 & 19 & 23 \\
\hline $60 \mathrm{~N}$ & 35 & 44 & 49 & 31 & 38 & 41 & 22 & 20 & 22 \\
\hline $70 \mathrm{~N}$ & 38 & 45 & 52 & 34 & 38 & 43 & 24 & 24 & 26 \\
\hline $80 \mathrm{~N}$ & 32 & 35 & 40 & 27 & 30 & 35 & 19 & 21 & 24 \\
\hline $50 \mathrm{Q}$ & 35 & 42 & 46 & 31 & 36 & 40 & 22 & 21 & 22 \\
\hline $60 Q$ & 29 & 35 & 36 & 28 & 30 & 31 & 19 & 18 & 20 \\
\hline $70 Q$ & 31 & 39 & 43 & 27 & 33 & 37 & 20 & 22 & 24 \\
\hline $80 \mathrm{Q}$ & 36 & 39 & 46 & 30 & 33 & 38 & 22 & 21 & 26 \\
\hline $\mathrm{CR}$ & 33 & 37 & 43 & 29 & 32 & 37 & 21 & 20 & 24 \\
\hline $\mathrm{T}$ & 34 & 34 & 38 & 30 & 28 & 30 & 22 & 20 & 23 \\
\hline
\end{tabular}

Treatments with removal of up to $70 \%$ of the basal area and involving greater removal of thin individuals showed higher gains in number of species, in comparison to treatments using the same removal intensities yet removing thicker individuals. Treatments with intensive removal such as $80 \mathrm{~N}, 80 \mathrm{Q}$ and CR, despite their slower recovery and lower than average gain in number of species, did not have a negative impact on the floristic composition.

Several Cerrado species have well developed root systems and thus reproduce vegetatively via the root buds or rhizomes, and this favors the recovery of areas subjected to intervention (FELFILI; SANTOS, 2002; RAMOS, 1990).

In the areas of this study it was observed that the path of succession is related not only to vegetative reproduction but also to the composition of existing propagules, that is, the seed bank in the soil and seed dispersion. This can be verified based on increased floristic richness and appearance of species typical of forests.

Through the analysis of floristic similarity, an interval of 0.538 to 0.958 was found for the Sorensen index. Figure 1 illustrates the formation of three distinct groups when a $25 \%$ cutting intensity is adopted in the scale axis of the dendrogram, as this is a determining point in the merging of similar clusters, according to MullerDombois and Ellenberg (1974). Group 1 includes areas prior to intervention, group 2 includes these areas after the application of different treatments, in 2004 and 2008, and group 3 refers to the control of the second and third inventory.
A clustering tendency was observed between treatments related to 2004 and 2008, suggesting there are more species in common between these inventories when compared to the inventory prior to interventions. Additionally, it was noted that changes in floristic composition also occurred in the control treatment, due to the effect of natural dynamics, preventing this treatment from falling into group 1 in 2004 and 2008.

According to Gauch (1982), a similarity index above 0.50 is considered high. A conclusion could thus be drawn, considering only the interval of values obtained, of high floristic similarity between vegetation before and after implementing the management regimes. However, this study refers to similarity in a single area over time and the high similarity found between measurements can be attributed to this fact, even if the area was subjected to interventions. Thus, by adding a dendrogram to the analysis it is possible to infer with more clarity the differences among the floristic composition of the three inventories and to realize, despite the high index values, that the vegetation eleven years after different levels of intervention differs from the original vegetation, including the control treatment.

Table 3 provides Shannon diversity index (H') and Pielou evenness index $(\mathrm{J})$ results, for the three measurement occasions, and also the Hutcheson t-test result. Values found for these indices are close to values found in other works, including the works of Araujo et al. (2007) and Scolforo et al. (2008).

Cerne, Lavras, v. 17, n. 1, p. 85-93, jan./mar. 2011 


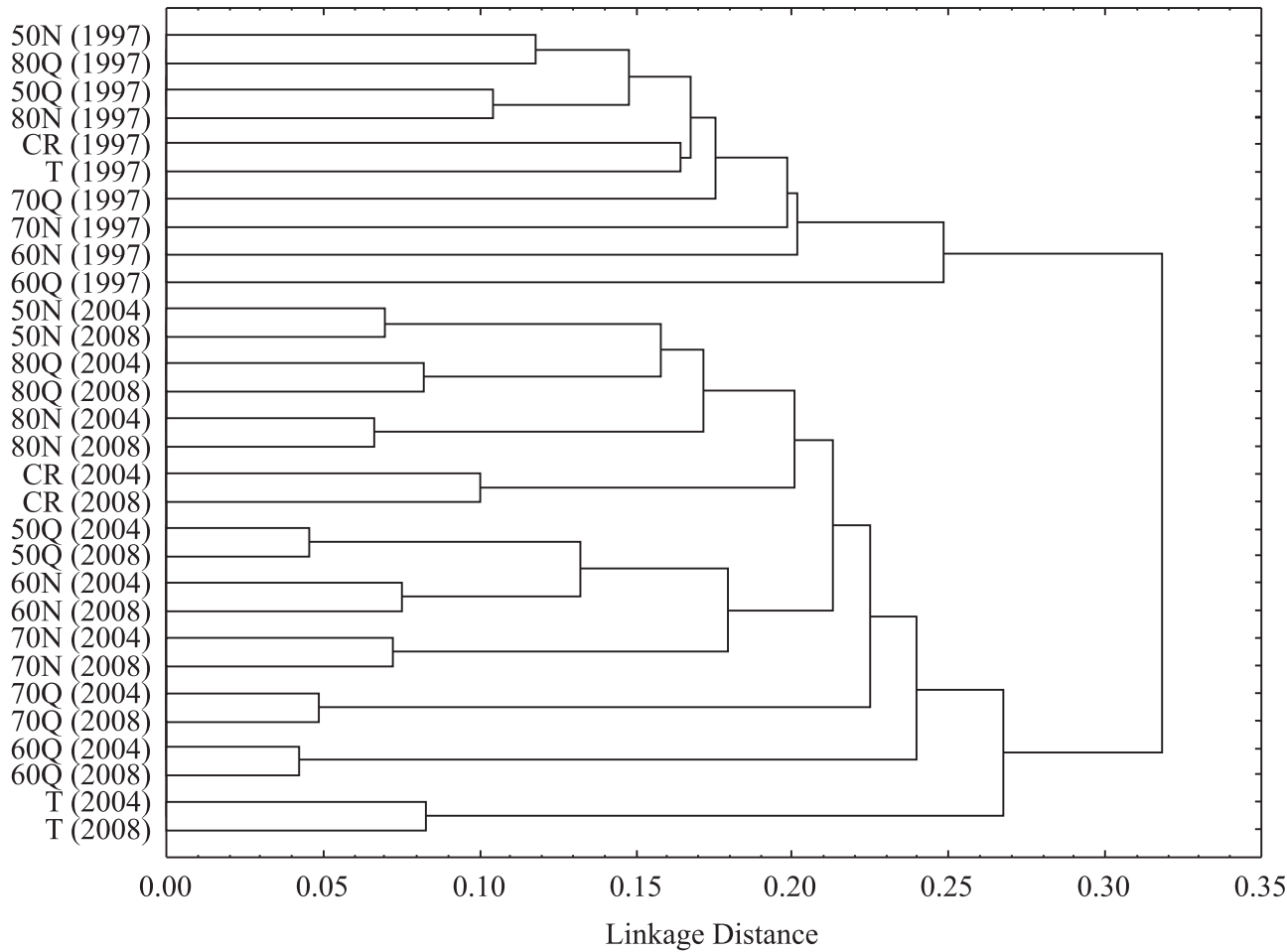

Figure 1 - Dendrogram based on the Sorensen similarity index for a Cerrado area, before (1997) and after (2004 and 2008) applying different management systems.

Figura 1 - Dendrograma gerado a partir do índice de similaridade de Sorensen para uma área de cerrado antes (1997) e após (2004 e 2008) a aplicação de diferentes sistemas de manejo.

Table 3 - Results of Shannon diversity index (H'), Pielou evenness index (J) and Hutcheson t-test, for each treatment, before (1997) and after (2004 and 2008) interventions. $\left(^{*}\right)$ indicates significant and (ns) indicates nonsignificant, at the 0.05 significance level, and $\mathrm{t}_{\text {tab }}$ value $=1.96$.

Tabela 3 - Índices de diversidade de Shannon ( $\left.H^{\prime}\right)$, equabilidade de Pielou $(J)$ e resultados do teste $t$ de Hutcheson, verificados em cada tratamento antes (1997) e após (2004 e 2008) as intervenções. Em que, $\left(^{*}\right)$ indica significativo e (ns) corresponde a não significativo, num nivel de significância igual a 0,05 , e valor de $t_{\text {tab }}=1,96$.

\begin{tabular}{cccccccccc}
\hline \multirow{2}{*}{ Treatment } & \multicolumn{3}{c}{ Shannon Index $\left(\mathrm{H}^{\prime}\right)$} & \multicolumn{3}{c}{ Hutcheson Test (t value) } & \multicolumn{3}{c}{ Pielou Evenness (J) } \\
& 1997 & 2004 & 2008 & $1997 / 2004$ & $2004 / 2008$ & $1997 / 2008$ & 1997 & 2004 & 2008 \\
\hline $50 \mathrm{~N}$ & 2.78 & 2.84 & 2.90 & $1.04(\mathrm{~ns})$ & $1.17(\mathrm{~ns})$ & $2.46\left(^{*}\right)$ & 0.79 & 0.77 & 0.76 \\
$60 \mathrm{~N}$ & 2.80 & 3.07 & 3.13 & $4.45\left(^{*}\right)$ & $1.09(\mathrm{~ns})$ & $6.06\left(^{*}\right)$ & 0.78 & 0.81 & 0.81 \\
$70 \mathrm{~N}$ & 2.89 & 2.99 & 3.09 & $1.58(\mathrm{~ns})$ & $1.53(\mathrm{~ns})$ & $3.50\left(^{*}\right)$ & 0.78 & 0.79 & 0.78 \\
$80 \mathrm{~N}$ & 2.68 & 2.83 & 2.93 & $2.53\left(^{*}\right)$ & $1.74(\mathrm{~ns})$ & $4.64(*)$ & 0.77 & 0.80 & 0.79 \\
$50 \mathrm{Q}$ & 3.00 & 3.08 & 3.15 & $1.51(\mathrm{~ns})$ & $1.30(\mathrm{~ns})$ & $2.92\left(^{*}\right)$ & 0.84 & 0.82 & 0.82 \\
$60 \mathrm{Q}$ & 2.79 & 2.82 & 2.86 & $0.53(\mathrm{~ns})$ & $0.62(\mathrm{~ns})$ & $1.31(\mathrm{~ns})$ & 0.81 & 0.79 & 0.80 \\
$70 \mathrm{Q}$ & 2.68 & 2.71 & 2.78 & $0.40(\mathrm{~ns})$ & $1.09(\mathrm{~ns})$ & $1.66(\mathrm{~ns})$ & 0.77 & 0.74 & 0.74 \\
$80 \mathrm{Q}$ & 2.89 & 3.07 & 3.12 & $3.02(*)$ & $1.01(\mathrm{~ns})$ & $4.23(*)$ & 0.80 & 0.84 & 0.82 \\
$\mathrm{CR}$ & 2.87 & 2.86 & 2.95 & $0.09(\mathrm{~ns})$ & $1.60(\mathrm{~ns})$ & $1.70(\mathrm{~ns})$ & 0.81 & 0.79 & 0.79 \\
$\mathrm{~T}$ & 2.78 & 2.68 & 2.76 & $1.80(\mathrm{~ns})$ & $1.43(\mathrm{~ns})$ & $0.42(\mathrm{~ns})$ & 0.78 & 0.76 & 0.76 \\
\hline
\end{tabular}

Cerne, Lavras, v. 17, n. 1, p. 85-93, jan./mar. 2011 
The above results demonstrate that the floristic diversity increased over the years in all areas subjected to vegetation removal, although, according to the Hutcheson test, treatments 60Q, 70Q and CR did not differ statistically between inventories. According to Santos and Vieira (2005), the Shannon diversity index $(\mathrm{H})$ also captures ecological succession, and, usually, areas in intermediate successional stages have a higher diversity index because they include both late and early successional species. As regards the control treatment, diversity responded differently from treatments subjected to intervention in that there was a decrease in floristic diversity, yet not significant. The fact that the control treatment showed lower diversity than areas subjected to intervention owes to species being in later successional stages there.

As regards Pielou evenness, a tendency was observed toward increasing concentration of abundances in few species, which dominate the community, as detected by the declining evenness indices found eleven years after the interventions, for most treatments involving vegetation removal. This behavior was also observed in the control. However, after checking the normality of data differences by the Shapiro-Wilk test between inventories (Table 4), it was demonstrate by the paired t-test (Table 4) that the evenness index found for year 2008 did not differ statistically from the evenness index found for year 1997.

According to Scolforo (1998), even when using a selective cut system, which is a set of silvicultural treatments, based on sustained production, local changes are inevitable. Areas undergoing change will be recolonized and their diversity and floristic composition will probably differ from those of the original forest.

Table 4 - Results of the Shapiro-Wilk test and paired t-test for the Pielou evenness index, for treatments before (1997) and after (2004 and 2008) interventions. ${ }^{*}$ ) indicates significant and (ns) indicates nonsignificant, both at the 0.05 significance level.

Tabela 4 - Resultado do teste Shapiro-Wilk e T-pareado para o índice de equabilidade de Pielou, considerando os tratamentos antes (1997) e após (2004 e 2008) a realização do manejo. Em que, ${ }^{*}$ ) indica significativo e (ns) corresponde a não significativo, ambos num nível de significância igual a 0,05.

\begin{tabular}{clllcccc}
\hline \multirow{2}{*}{ Inventory } & \multicolumn{2}{c}{ Shapiro-Wilk Test } & & \multicolumn{3}{c}{ Paired t-test } \\
\cline { 2 - 3 } & W Value & p-value & & $\begin{array}{c}\text { Mean of } \\
\text { differences }\end{array}$ & T Value & p-value \\
\hline $1997-2004$ & 0.0696 & $0.0988(\mathrm{~ns})$ & & 0.003 & 0.3862 & $0.3542(\mathrm{~ns})$ \\
$2004-2008$ & 0.8791 & $0.1274(\mathrm{~ns})$ & & 0.0057 & 2.6014 & $0.0143(*)$ \\
$1997-2008$ & 0.906 & $0.2546(\mathrm{~ns})$ & & 0.0087 & 1.2557 & $0.1204(\mathrm{~ns})$ \\
\hline
\end{tabular}

\section{CONCLUSIONS}

It can be concluded that, under the conditions of this study, the interventions applied to areas of Cerrado sensu stricto caused changes in both the floristic composition and diversity of the vegetation. However, these changes were also observed in the control treatment, that is, in areas not subjected to interventions.

\section{REFERENCES}

ALHO, C. J.; MARTINS, E. S. De grão em grão, o cerrado perde espaço. Brasília: WWF/PROCER, 1995. 66 p.

ANGIOSPERM PHYLOGENY GROUP. An update of the angiosperm phylogeny group classification for the orders and families of flowering plants: APG II. Botanical Journal of the Linnean Society, London, v. 141, n. 4, p. 399-436, Apr. 2003.

ARAÚJO, E. J. G. de; SOUZA, F. N. de; SCOLFORO, J. R. S.; MELLO, J. M. de; SILVA, C. P. C. Diversidade e estrutura de seis fragmentos de cerrado stricto sensu no extremo norte de Minas Gerais. Revista Brasileira de Biociências, Porto Alegre, v. 5, p. 546-548, jul. 2007. Suplemento 2. Disponível em: <http://www6.ufrgs.br/seerbio/ojs/index.php/rbb/index>. Acesso em: 10 jan. 2010.

BROWER, J. E.; ZAR, J. H. Field and laboratory methods for general ecology. Columbus: McGraw-Hill Higher Education, 1984. 240 p.

Cerne, Lavras, v. 17, n. 1, p. 85-93, jan./mar. 2011 
CARVALHO, L. M. T. de; SCOLFORO, J. R. S. Inventário florestal de Minas Gerais: monitoramento da flora nativa 2005-2007. Lavras: UFLA, 2008. 357 p.

DRUMMOND, G. M.; MARTINS, C. S.; MACHADO, A. B. M.; SEBAIO, F. A.; ANTONINI, Y. A. Biodiversidade em Minas Gerais: um atlas para sua conservação. Belo Horizonte: Fundação Biodiversitas, 2005.

FELFILI, J. M.; SANTOS, A. A. B. Direito ambiental e subsídios para a revegetação de áreas degradadas no Distrito Federal. Brasília: UnB, 2002. v. 4, 135 p. (Comunicações Técnicas Florestais, 2).

FERREIRA, D. F. Estatística básica. Lavras: UFLA, 2005. $664 \mathrm{p}$.

FIEDLER, N. C.; AZEVEDO, I. N. C.; REZENDE, A. V.; MEDEIROS, M. B.; VENTUROILI, F. Efeito de incêndios florestais na estrutura e composição florística de uma área de cerrado Sensu Stricto na Fazenda Água Limpa-DF. Revista Árvore, Viçosa, v. 28, n. 1, p. 129-138, jan./fev. 2004.

GAUCH, H. G. Multivariate analysis in community ecology. Cambridge: University, 1982. 298 p.

GOMES, A. P. C.; SOUZA, A. L. de; MEIRA NETO, J. A. A. Alteração estrutural de uma área florestal explorada convencionalmente na bacia do Paraíba do Sul, Minas Gerais, nos domínios de floresta atlântica. Revista Árvore, Viçosa, v. 28, n. 3, p. 407-417, 2004.

KENT, M.; COKER, P. Vegetation description andanalysis, a practical approach. London: Belhaven, 1992. 363 p.

LORENZI, H. Árvores brasileiras. Nova Odessa: Plantarum, 1992.

MAGURRAN, A. E. Ecological diversity and its measurement. Cambridge: University, 1988. 192 p.

MARTINS, F. R. Estrutura de uma floresta mesófila. Campinas: Unicamp, 1993. 246 p.

MARTINS, S. V. Aspectos da dinâmica de clareiras em uma floresta estacional semidecidual no município de Campinas, SP. 1999. 233 p. Tese (Doutorado em Biologia Vegetal) Universidade Estadual de Campinas, Campinas, 1999.

Cerne, Lavras, v. 17, n. 1, p. 85-93, jan./mar. 2011
MUELLER-DOMBOIS, D.; ELLENBERG, H. Aims and methods of vegetation ecology. New York: J. Willey, 1974. $574 \mathrm{p}$.

OLIVEIRA, A. D. de; LEITE, A. P.; BOTELHO, S. A.; SCOLFORO, J. R. S. Avaliação econômica da vegetação de cerrado submetida a diferentes regimes de manejo e de povoamentos de eucalipto plantado em monocultivo. Cerne, Lavras, v. 4, n. 1, p. 34-56, jan./jun. 1998.

OLIVEIRA, M. C. de; SCOLFORO, J. R. S.; MELLO, J. M. de; OLIVEIRA, A. D. de; ACERBI JÚNIOR, F. W. Avaliação de diferentes níveis de intervenção na florística, diversidade e similaridade de uma área de cerrado stricto sensu. Cerne, Lavras, v. 12, n. 4, p. 342-349, out./dez. 2006.

OLIVEIRA, Y. M. M. de; ROTTA, E. Levantamento da estrutura horizontal de uma mata de araucária do primeiro planalto paranaense. Boletim de Pesquisa Florestal, Curitiba, n. 4, p. 1-46, jun. 1982.

R DEVELOPMENT CORE TEAM. R: a language and environment for statistical computing. Vienna: R Foundation for Statistical Computing, 2009.

RAMOS, A. E. O efeito da queima sobre a vegetação lenhosa do cerrado. 1990. 142 p. Dissertação (Mestrado em Ecologia) - Universidade de Brasília, Brasília, 1990.

RATTER, J. A.; DARGIE, T. C. D. An analysis of the floristic composition of 26 cerrado areas in Brazil. Edinburgh Journal of Botany, Edinburgh, v. 49, n. 2, p. 235-250, 1992.

REIS, H.; SCOLFORO, J. R. S.; OLIVEIRA, A. D. de; OLIVEIRA FILHO, A. T. de; MELLO, J. M. de. Análise da composição florística, diversidade e similaridade de fragmentos de mata atlântica em Minas Gerais. Cerne, Lavras, v. 13, n. 3, p. 280-290, jul./set. 2007.

SANTOS, R. M. dos; VIEIRA, F. de A. Análise estrutural do componente arbóreo de três áreas de cerrado em diferentes estádios de conservação no município de Três Marias, Minas Gerais, Brasil. Cerne, Lavras, v. 11, n. 4, p. 399-408, ago. 2005.

SCOLFORO, J. R. S. Manejo florestal. Lavras: UFLA/ FAEPE, 1998. 438 p. 
SCOLFORO, J. R. S.; OLIVEIRA, A. D. de; FERRAZ FILHO, A. C.; MELLO, J. M. de. Diversidade, equabilidade e similaridade no domínio do cerrado. In: SCOLFORO, J. R. S.; MELLO, J. M. de; OLIVEIRA, A. D. de. Inventário florestal de Minas Gerais: cerrado: florística, estrutura, diversidade, similaridade, distribuição diamétrica e de altura, volumetria, tendências de crescimento e áreas aptas para manejo florestal. Lavras: UFLA, 2008. cap. 7, p. 267-358.

SILVA, C. P. C.; OLIVEIRA FILHO, A. T. de; BERG, E. van den; SCOLFORO, J. R. S.; MELLO, J. M. de; OLIVEIRA, A. D. de. Composição florística no domínio do cerrado. In: SCOLFORO, J. R. S.; MELLO, J. M. de; OLIVEIRA, A. D. de. Inventário florestal de Minas

Gerais: cerrado: florística, estrutura, diversidade, similaridade, distribuição diamétrica e de altura, volumetria, tendências de crescimento e áreas aptas para manejo florestal. Lavras: UFLA, 2008. cap. 3, p. 135-168.
SNEATH, P. H.; SOKAL, R. R. Numerical taxonomy. New York: W. H. Freeman, 1973.

STATSOFT. Statistica: data analysis software system. Version 7. [S.1.], 2004. Disponível em: <www.statsoft.com>. Acesso em: 10 mar. 2006.

TEIXEIRA, M. I. J. G.; ARAÚJO, A. R. B.; VALERI, S. V.; RODRIGUES, R. R. Florística e fitossociologia de área de cerrado s.s., no município de Patrocínio Paulista, nordeste do estado de São Paulo. Bragantia, Campinas, v. 63, n. 1, p. 1-11, jan./abr. 2004.

WAKEEL, A.; RAO, K. S.; MAIKHURI, R. K.; SAXENA, $\mathrm{K}$. G. Forest management and use/cover changes in a typical micro watershed in the mid elevation zone of Ventral Himalaya, India. Forest Ecology and Management, Amsterdam, v. 213, n. 1/3, p. 229-242, July 2005. 